\title{
Gender Dimension And Disparity In Vegetable Picking
}

\author{
Rashed Saeed \\ Arshed Bashir \\ Muhammad Qasim \\ \& \\ Sonila Hassan \\ Social Sciences Research Institute, Faisalabad
}

\begin{abstract}
Gender involvement in agriculture is becoming more asymmetrical in rural areas due to differences in wages of respective labour resultantly affecting health, wealth and decision making power of women engaged in agriculture. Study, therefore, was planned to investigate status of women engaged in vegetable picking and see constraints faced by them. Descriptive statistics are used to analyze primary data collected during year 2013. Results reveal that average monthly household income and expenditure were Rs. 10770 and Rs. 9291. Average daily earnings of males and females from vegetable picking were Rs. 333 and Rs.156 respectively which clearly shows disparity regarding wage rates. Female respondents were earning income also from other off-season sources in order to support family budget. Majority of female respondents $(86 \%)$ were aware about harmful health effects of pesticides' sprays on vegetables but they were still not using appropriate safety measures. They complained about different diseases while working in vegetable fields. It is suggested that training in other more remunerative non-farm/ off-season activities should be provided to females in order to improve wages on competitive basis. The pickers should be educated also about the importance of using safety precautions while working in vegetables fields.
\end{abstract}

Key words: Gender, disparity, dimension, picking, vegetable, wages

$$
\begin{aligned}
& \text { تخصص }
\end{aligned}
$$

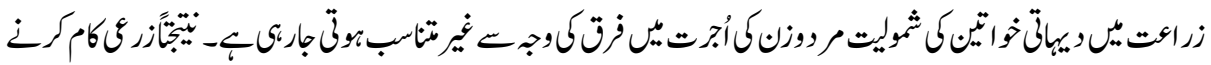

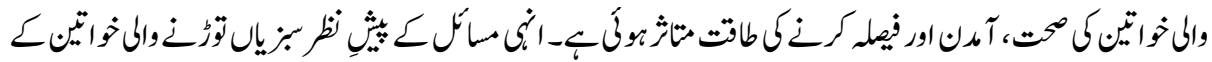

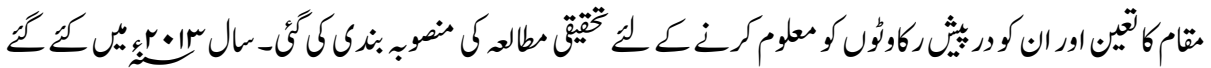

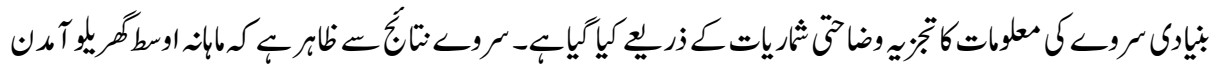

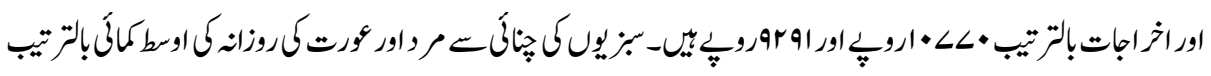

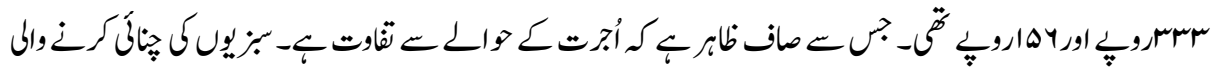




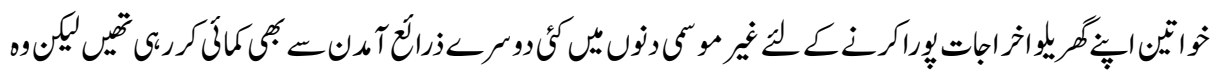

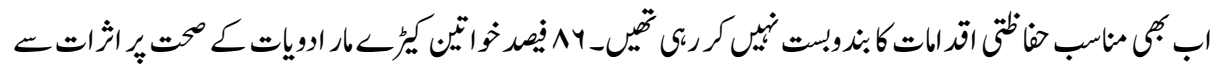

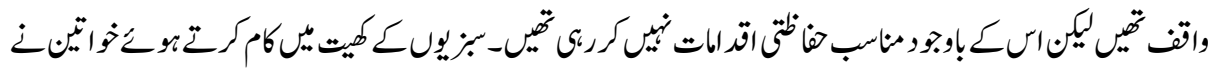

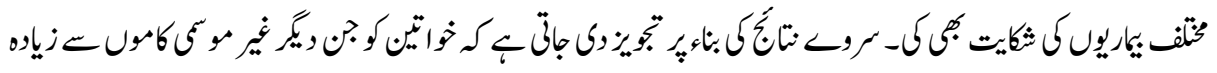

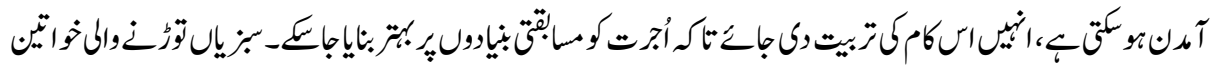

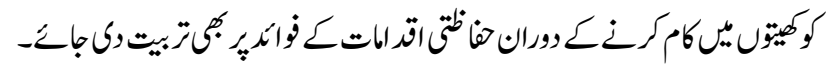

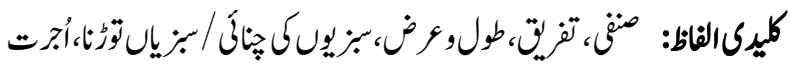

\section{Background and Objectives}

Many vegetables are grown during different seasons across all regions of country due to short plantation duration and low delta nature of vegetable crops (Memon, 2013). Pakistani women play a key role in agriculture sector. Literature reflects that women comprise, on average, $43 \%$ of the agricultural labour force in developing countries (FAO, 2011). A rural woman in Pakistan works for 12-16 hours a day on farm, off-farm and at home activities throughout year and participates in most of field operations including sowing, weeding, tending, harvesting, storage of crops, fodder collection, livestock management, fetching water from far flung areas, cooking, fuel collection, washing/cleaning and caring of children, etc. (Mamoona, 2004). Gender does not concern women alone; it involves the roles of both women and men in fields of production, use, health, welfare, etc. Anonymous (2008) reported that rural women contribute almost 60 per cent in the agriculture. But they face several constraints in approaching agricultural departments for facilities similar to those available to their male counterparts. In the southern regions of Pakistan, a husband may marry more than one woman to supply additional farm labour.

On one hand, females are treated as unskilled labour due to low level of education and skills among them and on the other hand, male dominance in decision making in household and economy has continued even in areas where women are key providers of labour because the influence of women has not been recognized (Greene, 2000). This situation implies that gender involvement is becoming more asymmetrical in rural areas due to differences in working hours, nature of tasks and respective wages of labour as well as due to the power imbalances between males and females. All this has resultantly affected health, wealth and decision making power of the women engaged in vegetable production. By eliminating the gap between men and women in access to agricultural 
resources and inputs would raise yields on women's farms by 20-30 percent and increase agricultural production in developing countries by 2.5-4 percent, which could in turn reduce the number of undernourished people in the world by 12-17 percent or 100-150 million people. Equal access to resources will raise total agricultural output in developing countries by $2.5-4$ percent (FAO, 2011).

For solving problems faced by women in crop production activities, care is neither considered by men nor by government. Women are also unaware of most of advanced crop production activities and technologies due to lack of training facilities and resources. If some training is organized by some agencies, then rural females are not permitted to join by male members due to sex discriminatory society (World Bank, 2001). Their needs, interests, and constraints are not reflected in policy-making. They also have limited access to benefits of research and innovations. A report of UNDP (2004) describes that women are uncountable and eat leftover food after eating of males. They take their food at minimum protein level causing different diseases. Available information is limited about role of rural women in vegetable picking and problems/ constraints faced during picking and other farm activities. Study was, therefore, planned to investigate the socioeconomic status of rural women engaged in vegetable picking with following other objectives.

\section{Objectives}

1. To find out the socio-economic characteristics of female vegetable pickers.

2. To find out the involvement of women in picking and constraints faced by them during picking.

3. To see the level of decision-making powers between men and women in domestic and external affairs.

4. To suggest recommendations for solving problems of female vegetable pickers.

\section{Materials and Methods}

Initially, review of literature and consultations were conducted with the agricultural experts especially the Vegetable Research Institute in Faisalabad in order to make detailed planning of study. The study has made use of both the qualitative and quantitative methods of data collection. Though study was entirely based on primary data but information from secondary sources was also used while planning for the survey. Study area comprised of three tehsils of two Districts of Punjab Province i.e. District Faisalabad and Nankana Sahib. Two tehsils of Faisalabad district i.e. Chak Jhumra and Faisalabad and one teshsil of District Nankana Sahib i.e. Nankana Sahib were selected in 
order to collect primary data during the year 2013. From these tehsils, vegetable growing villages were selected in consultation with local Vegetable Research Institute and Extension Department. Structured questionnaire with close ended and open ended questions was designed for farm level data collection from female vegetable pickers. A total of 150 female respondents (50 from each Tehsil) from the study area were randomly selected and interviewed. The collected data was analyzed using different econometric techniques to achieve the specific objectives of study. Descriptive statistics such as minimum, maximum, average values, frequencies and percentages of different farm activities were calculated.

\section{Results and Discussion}

The results of the research provide insight into the roles and activities of female vegetable pickers in vegetable picking, and their involvement in domestic matters. Moreover the study results highlight the respondents' expectations from government for better picking operations and economic well-being.

\section{Socio-Economic Profile of Vegetable Pickers}

Women in younger age group have been found actively working in domestic, agricultural and many other commercial sectors. Table 1 shows that average age of the female vegetable picker was 36.81 years ranging from minimum 14 to maximum 65 year. Average age of 36 years implies that women falls under working-age, not under old-age. Farooq and Sulaiman (2007) also found very close results regarding average age of female labour in Pakistan (which is 32 years). Taj et al. (2009) also found that average age of females working in agricultural fields was 40 years in study area of District Attock. If we look at the education indicator, then average education of sample respondents was 2.11 classes only ranging from minimum 0 (illiterate) to maximum 12 classes. Lower literacy level may be one of the reasons behind weak empowerment and decision-making powers of gender as empowerment and decision- making are also measured by human capital. Average family size was 6.34 persons. Average number of children per family was 3.53 ranging from minimum 0 to maximum 10 children whereas the average number of male was 2.09 with minimum 0 to maximum 7 males. Average number of female per family was 2.43 whereas minimum and maximum females were 1 and 8 respectively. Average number of family members involved in vegetable picking was 2.19. In terms of males and females in picking, 0.58 and 1.5 numbers were males and females in picking respectively. 
Average earning of females from vegetable picking was Rs. 156.16 ranging from minimum 50 to maximum 375 rupees / day which is lower as compared to their counterpart male labour whose average earning was Rs. 333.33 (almost double of female earnings) ranging from minimum Rs. 300 to maximum Rs. 375 per day. It is evident from study findings that women labour force was being discriminated/ exploited on the grounds of wage rate. The wage gap in earnings may be due to both of human capital difference or pure discrimination. Farooq and Sulaiman (2007) found that nearly 75 to 85 percent wage gap is due to discrimination in labour market of Pakistan. In India, average wage for agricultural casual work is 30 percent less for women as compared to men, 20 percent lower for the same task (FAO, 2009). Similar results were also found in FAO (2011) report wherein men's wages are 31 percent higher than women's wages in urban areas and 58 percent higher in rural areas of Ghana Country. Other researchers like Farooq and Sulaiman (2007) reported that male labour with same characteristics was earning 182 percent more than female labour monthly earnings in Pakistan. They further observed that gender inequalities exist in all labour markets but creating a near-balance situation is equally fruitful. Literature suggests wage gap has narrowed down but still problem exists. If wages of both the gender are brought equal then 6 percent expansion of the growth would be possible (FAO, 2009).

Average family income per month from all sources was Rs.10770 ranging from minimum 3000 to maximum 32000 rupees per month. Similarly, average family expenditures out of the earned income were Rs.9291 per month ranging from minimum 2000 to maximum 30000 rupees per month. Income expenditure statistics reflect that household saves little amount (Rs.1479) per month for their future needs (Table 1).

Table: 1

Socio-Economic Profile of Vegetable Pickers

\begin{tabular}{|l|c|c|c|c|}
\hline Characteristics & Mean & Minimum & Maximum & STDV \\
\hline Women's age & 36.81 & 14 & 65 & 11.09 \\
\hline Women's education & 2.11 & 0 & 12 & 3.263 \\
\hline Family size (Nos.) & 6.34 & 4 & 15 & 3.16 \\
\hline No. of children in family & 3.53 & 0 & 10 & 2.792 \\
\hline No. of males in family & 2.09 & 0 & 7 & 1.397 \\
\hline No. of females in family & 2.43 & 1 & 8 & 1.777 \\
\hline Members involved in picking (Nos.) & 2.19 & 1 & 5 & 0.964 \\
\hline No. of males in picking & 0.58 & 0 & 4 & 0.698 \\
\hline No. of females in picking & 1.53 & 1 & 5 & 0.79 \\
\hline Daily earning of males from picking (Rs.) & 333.33 & 300 & 375 & 31.285 \\
\hline Daily earning of females from picking (Rs.) & 156.16 & 50 & 375 & 51.870 \\
\hline Monthly family income (Rs.) & 10770 & 3000 & 32000 & 5500.848 \\
\hline Monthly family expenditure (Rs.) & 9291 & 2000 & 30000 & 5203.883 \\
\hline
\end{tabular}

Source: Authors' Survey 2013 


\section{Demographic Characteristics and Livelihood Strategies}

The majority of vegetable pickers (62 percent) belonged to agricultural background while females belonging to non-agricultural background were 38 percent. This result implies that majority of the respondents were surviving on agriculture. Majority of the families (50.7 percent) were living in the Pacca houses followed by 27.3 and 22 percent living in Kacha and Semi-Pacca houses respectively. Results show that Kacha houses are still present in a significant number. Majority of the vegetable pickers (51 percent) were living in joint family system whereas remaining (nearly 50 percent) had nuclear family system. These results indicate that neither nuclear nor joint family system was significantly prominent in the study area. Most of the respondents (74.7 percent) were married, which shows that these women have to share the family responsibilities in addition to certain field assignments. There was significant number (16 percent) of unmarried girls in the study area. The sample of respondents also contained unmarried pickers (9.3 percent). According to majority of respondents ( 74 percent), caring family matters was the most common activity instead of doing agricultural works whereas 19.3 percent females were doing job in addition to looking after the family matters. While a small number of females were much active for whom both the family and job matters were important and these were successfully running such activities at the same time. Majority of respondents (70.7 percent) did not consider the job as a burden. On the other hand, females who were doing job as a burden were not in a small percentage (29.3 percent). Most of the vegetable pickers (almost three fourth) considered this job as a burden because of tiredness or difficulty in continuing job in the presence of other family tasks. While 27.27 percent said that the job is not paying well due to low salaries in this age of inflation. 
Table: 2

Demographic Characteristics and Livelihood Strategies of Vegetable Pickers

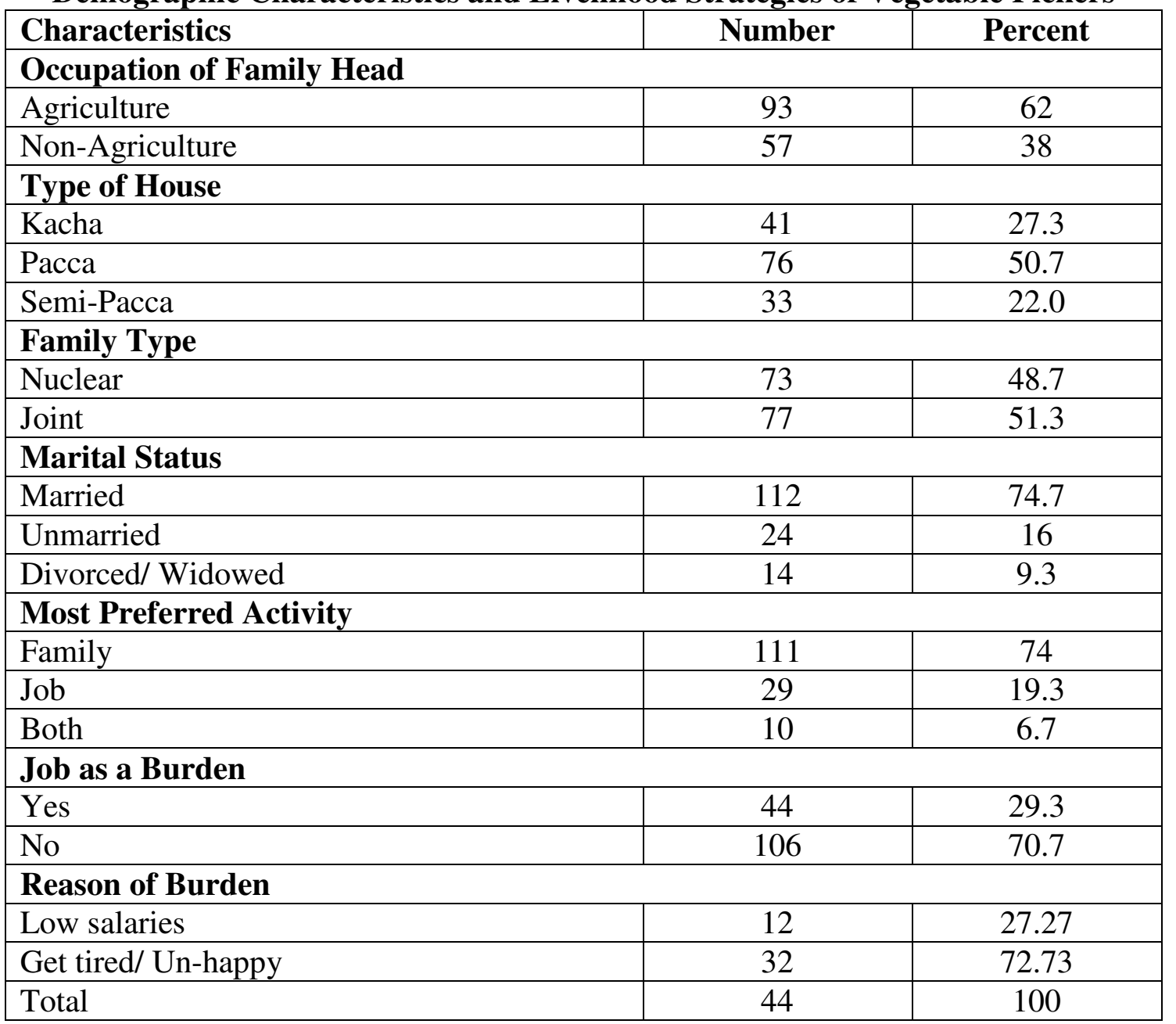

Source: Authors' Survey 2013

\section{Working Environment during Picking}

Results depict that females were doing vegetables picking mainly for two reasons i.e. domestic needs and self-empowerment purposes. It is evident that majority (82.7 percent) was doing picking for meeting their domestic needs whereas 17.3 percent were performing picking for their self-empowerment (freedom of incurring expenditures according to own wishes). Rural wage employment goes mostly in favor of women as compared to men regarding availability of off-season jobs but women are more likely to be employed on lower wage rates in many developing countries. For example in Bangladesh and Malawi, women in off-season jobs were receiving much lower wages 
even below the median agricultural wage (FAO, 2010-11). Results indicate that 84.6 percent of the respondents were having other sources of income while 15.4 percent were not performing other works like sewing, running beauty parlor and tuition centre, embroidery etc. This result indicates that women also perform numerous time consuming activities to supplement their family expenditures. Vegetable pickers were not totally relying on vegetable picking for their expenditures but had alternative sources of income in off-season like cloth sewing/ stitching, embroidery, farm cultural operations, milk selling, running tuition centre and beauty parlor etc as described in table 3. Majority (38.6 percent) were doing stitching followed by second large majority (17.3 percent) who was selling milk to supplement their domestic needs. While 15 percent of respondents were performing other farming tasks like seed cleaning, sowing, hoeing, or cleaning farm sheds etc. Very few respondents (almost total 7) were running tuition centre and beauty parlor. Anyhow, no respondent was staying idle at home during off-season of vegetables. Taj et al. (2009) also found similar result that women spend more leisure time in stitching and embroidery activities at home. Almost all the respondents ( 96 percent) reported that involvement in vegetable picking activity has improved their financial conditions.

Table: 3

Working Environment during Picking

\begin{tabular}{|l|c|c|}
\hline Responses & Number & Percent \\
\hline Purpose of Picking & 124 & 82.7 \\
\hline Domestic needs & 26 & 17.3 \\
\hline Self-empowerment & 127 & 84.6 \\
\hline $\begin{array}{l}\text { Availability of Alternative Income Sources in } \\
\text { Off-Season }\end{array}$ & \multicolumn{1}{|l|}{} \\
\hline Nature of Alternative Income Sources & 49 & 38.6 \\
\hline Cloth sewing/ Stitching & 17 & 13.4 \\
\hline Embroidery & 22 & 17.3 \\
\hline Milk Selling & 19 & 15 \\
\hline Farm cultural operations & 13 & 10.2 \\
\hline Wood Cutting & 5 & 3.9 \\
\hline Beauty Parlor & 2 & 1.6 \\
\hline Tuition & 127 & 100 \\
\hline Total & 144 & 96 \\
\hline Respondents opinion about the working environment & 72 \\
\hline Improvement in Livelihood due to Picking & 108 & 84 \\
\hline Provision of Transport Facility & 126 & 80 \\
\hline Role of Training Facility in Picking Activities & 120 & \\
\hline Drinking Water Availability on Farm & 116 & 77.3 \\
\hline $\begin{array}{l}\text { Men's Positive Attitude towards Female } \\
\text { Vegetable Picking }\end{array}$ & & \\
\hline
\end{tabular}


Source: Authors' Survey 2013

Majority of the respondents (72 percent) said that farmers did not provide the transport facility to them while remaining told that transport was available from farmers end. It means that lack of transport facility was a serious issue in study area. Vegetable harvesting was seasonal and pickers used to travel great distances for finding work, depending on the time of year. A large majority (84 percent) said that the training facility would improve the performance of vegetable picking whereas 16 percent were not supporting the view about role of training in improving picking practices. However, training services may be important during all the stages of vegetable growing especially at the time of pesticide and fertilizer applications. Similarly, majority of respondents (80 percent) reported that water according to the hot or cold weather was available for drinking during picking activities while remaining 20 percent negated this statement/ facility. This situation needs attention of the farmers that clean drinking water according to weather situations may not be a problem on ethical grounds. Majority of the women (77.3 percent) said that their family male members were willing to accept their participation in field works whereas 22.7 percent reported that male members did not favor the works of women in agriculture and even disliked the mobility of women outside the homes.

\section{Vegetable Picking Attributes and Timing}

Survey results further indicate that the average picking days in a season were 65.6 (more than two months) with minimum 23 days (less than a month) to maximum 150 days (5 months). Vegetable pickers generally work in a variety of weather conditions. Work conditions can range from hot and sunny, to cold, wet and windy, depending on the location and time of year. It is further evident from the table 4 that average number of days spent in picking came to 20.4 days with minimum 12 to maximum one month if picking days are counted in terms of months. Table 4 further reflects that average spent time by females in field was 7.1 hours ranging from minimum 2 to maximum 12 hours in a day. Mostly female workers were paid according to the amount of produce they pick, so these females had to work quickly and for long hours. Study results corresponds with study of Mamoona (2004) who found that a rural woman in Pakistan works for 12-16 hours a day on farm, off-farm and at home activities throughout the year and participates in most of the field operations including sowing, weeding, tending, harvesting, storage of crops, fodder collection, livestock management, fetching water from far flung areas, cooking, fuel collection, washing/cleaning and caring of children, etc. Taj et al. (2009) also studied somewhat same long working hours for rural woman who have to work between 25-35 hours per week in household activities excluding 
childcare. Similarly, Josupeit (2004) noted more than 8 hours per day working schedule of females in fields. It is evident from the table that on average pickers entered into their agricultural fields after 17.8 hours after pesticides spray. Minimum interval followed was 10 hours and maximum was 25 hours (more than one day) of spray. It was observed in the field that certain farmers were offering vegetables to the male as well as female pickers free of cost (as a generosity). Survey results further show that average quantity of offered vegetables per day as a courtesy was $1.55 \mathrm{Kg}$ per day. Zero quantity means that vegetable owners were not bound to offer vegetables to all the vegetable pickers as a generosity or in return to certain petty works. It depends only on the social attitude of farmers.

Table: 4

Vegetable Picking Attributes and Timing

\begin{tabular}{|l|c|c|c|c|}
\hline Characteristics & Mean & Minimum & Maximum & STDV \\
\hline Total picking days in a season & 65.6 & 23 & 150 & 34.914 \\
\hline Total picking days in a month & 20.43 & 12.0 & 30.0 & 5.674 \\
\hline Spent time by females in field (hours/ day) & 7.1 & 2 & 12 & 2.185 \\
\hline Vegetables quantity (Kg/day) & 1.55 & 0 & 4 & 0.957 \\
\hline $\begin{array}{l}\text { Time interval between spray and entrance } \\
\text { into the fields (hours) }\end{array}$ & 17.8 & 10 & 25 & 4.100 \\
\hline
\end{tabular}

Source: Authors' Survey 2013

\section{Income and Expenditure Aspects of Vegetable Pickers}

Almost all (96.7 percent) respondents were receiving payment to their work in cash-form whereas meager number of respondents, (only 5) reported in-kind payment mode. Majority of vegetable pickers (87.0 percent) received their wages on spot (on the same day of work) while only 13 percent pickers got their wages after one or few days as agreed by both parties. These results show that the workers were often paid on spot according to the amount of produce they picked and the time they spent in picking. It is observed that income earned from various sources of family was spent mainly on four heads like household, children education, dowry making and self-empowerment of the females (Table 5). Moreover, majority of respondents (58 percent) spent their income for meeting household needs whereas second major head of budget consumption was children's education. Taj et al. (2009) also found that both male and female workers

mostly spend their family income in meeting household needs. Results reflect that 
purpose of earning income for self-empowerment of the females and dowry making as well as health expenses of family could not be realized well due to little left amount and least priority attached to these heads of expenditures in the presence of rising domestic needs.

Table: 5

Income and Expenditure Aspects of Vegetable Pickers

\begin{tabular}{|l|c|c|}
\hline Responses & Number & Percent \\
\hline Payment Mode & 145 & 96.7 \\
\hline Cash & 5 & 3.3 \\
\hline In-Kind & 137 & 91.3 \\
\hline Wages Payment Time & 13 & 8.7 \\
\hline On same day & \multicolumn{2}{|l|}{} \\
\hline Delayed & 87 & 58 \\
\hline Main Income Expenditure Heads & 33 & 22 \\
\hline Household expenditures & 16 & 10.7 \\
\hline Children education & 14 & 9.3 \\
\hline Self-empowerment of picker (freedom of expenses) &
\end{tabular}

Source: Authors' Survey 2013

\section{Problems Faced During Picking}

A large majority of vegetable pickers (72 percent) were aware and following some precautionary measures during picking while 28 percent did not follow any precautionary measures. It is alarming that still significant number of pickers were not using precautionary measures like hand gloves, wearing of socks and shoes and veiling the face with mask or cloth during picking, fertilizer and pesticide application times. Another majority (55.6 percent) among 108 number of user of precautionary measures was using socks, shoes and safety gloves to save naked organs of their body from harmful effects of pesticides or fertilizers. Similarly, a significant percentage of respondents (44.4 percent) were only covering their face with cloth in order to protect themselves from harmful effects of diseases and pesticides/ sprays. This implies that use of recommended and proper precautionary materials was not being followed. Majority (80 percent) said that first aid/ medical facility was adequate in their villages while remaining 20 percent claimed lack of such facilities in their villages. It indicates that rural people were still in dire need of better medical facilities especially at the time of emergency. More than half 
of rural population was deprived of quality health facilities according to monthly report of Free and Fair Election Network (FAFEN, 2010). Majority of pickers (66 percent) visited their village dispenser / doctor whereas 15.3 percent pickers obtained health facility from Hakeem in case of any emergency occurred at farms. It implies that role of Hakeem is still recognized in the wake of modern world of science and technology. Women face health hazards depending upon the extent of work and working conditions. For example, women in the rice cultivation and weeding were found reporting pelvic and back bone pains. Though both the genders perform onerous tasks in the fields but females have to face more problems / exposures to some risks as a result of females' involvement for the longer period in certain concentrated activities. Results indicate that certain diseases like asthma, cough, headache, skin and eye irritations, fever and allergy etc. was faced by females during picking of vegetables but majority of respondents reported no particular disease affecting the human health. Contrary to it, headache seems one of the diseases wherein significant number of respondents (33.3 percent) interviewed it as a major health risk. Whether such diseases occur or not, precautionary measures should be followed to avoid potential health risks associated with farming activities.

Table: 6

Problems Faced During Picking

\begin{tabular}{|c|c|c|}
\hline Response & Number & Percent \\
\hline $\begin{array}{l}\text { Awareness and Use of Precautionary Measures during } \\
\text { Picking }\end{array}$ & 108 & 72 \\
\hline \multicolumn{3}{|l|}{ Specification of Measures } \\
\hline Hand Gloves/ Cloths Wearing & 48 & 44.4 \\
\hline $\begin{array}{l}\text { Socks and shoes wearing properly covering hands and the } \\
\text { face }\end{array}$ & 60 & 55.6 \\
\hline Availability of Medical Facility & 120 & 80 \\
\hline \multicolumn{3}{|l|}{ Referral to Doctor or Hakeem in Emergency } \\
\hline Hakeem & 23 & 15.3 \\
\hline Dispenser/ Doctor & 99 & 66 \\
\hline No Response & 28 & 18.7 \\
\hline \multicolumn{3}{|l|}{ Diseases due to Vegetable Picking } \\
\hline Headache & 50 & 33.3 \\
\hline Eye Irritation & 21 & 14.0 \\
\hline Skin Irritation & 39 & 26.0 \\
\hline Fever & 25 & 16.7 \\
\hline Asthma & 13 & 8.7 \\
\hline Cough & 31 & 20.7 \\
\hline Allergy & 9 & 6.0 \\
\hline
\end{tabular}


Source: Authors' Survey 2013

\section{Gender Empowerment to Economic and Social Functions}

Results indicate that females have comparatively more powers as compared to male member/head regarding saving and consumption, household activities and attending the communal functions but on the other hand, male has dominant hand regarding decision of children marriages.

Table: 7

Gender Empowerment to Economic and Social Functions

\begin{tabular}{|l|c|c|}
\hline \multirow{2}{*}{ Decision Making Dimensions } & \multicolumn{2}{|c|}{ Powers of Females } \\
\cline { 2 - 3 } & Number & Percent \\
\hline Saving and consumption & 106 & 70.7 \\
\hline Household activities & 124 & 82.7 \\
\hline Children marriages & 70 & 46.7 \\
\hline Women's say in communal affairs & 78 & 52.0 \\
\hline
\end{tabular}

Source: Authors' Survey 2013

\section{Conclusions and Recommendations}

Keeping in view the survey data, formal and informal field visits, female vegetable pickers in both Districts i.e. Faisalabad and Nankana Sahib were found actively performing agricultural activities especially vegetable picking. Literacy rate was generally low (below primary level) which may be one of the reasons of working for long hours on low wages, lack of bargaining and decision-making powers, as well as the lack of awareness for adoption of proper precautionary measures during picking activities. Mostly women were falling in age group of 30 to 40 years (means not old enough) for carrying out labourious farm and family assignments. Females vegetable pickers were performing numerous other labour intensive jobs such as cloth sewing/ stitching, milk selling, running beauty parlor and tuition center etc. in the off-season in order to support family budget. Female pickers were forced to pick vegetables although monetary payments were too low. The main reason for the low participation of women seems social one because these were unskilled and less educated resultantly bound to accept low wages and increased workloads without complaining as compared to male labour force. In addition to low wages, vegetable pickers were facing certain other problems like lack of transport and training facility as well as non-availability of adequate emergency care. 
Availability of clean drinking water at the farms in appropriate seasons was another notable problem in the study area.

Despite these constraints, vegetable picking activities improved their financial conditions. Women got wages on daily basis and mostly got some vegetables from the owners as a generosity at the end of day. Women were more exposed to pesticides that adversely impacted their health. Although a little bit awareness about harmful effects of pesticide/ fertilizers was present yet the use of proper precautionary measures/ materials during vegetable picking was not adopted. Respondents highlighted certain diseases such as headache, allergy, eye and skin irritation and fever etc while doing picking. There was shortage of emergency medical facility in rural areas as majority of pickers use to visit village dispensers and some were still approaching to Hakeem in case of emergency instead of visiting to doctor. It implies that role of Hakeem is not negligible in the wake of modern world of science and technology. Although female pickers were supporting their husbands in running domestic affairs smoothly through participation in household activities like consumption and saving as well as involvement in community functions yet females could not independently take decisions regarding the children marriages and selfempowerment (spending income according to their wishes).

Female vegetable pickers should be provided training in other more remunerative nonfarm activities like stitching for readymade garments, fashion designing, beauty parlor, and preparation of value added products of fruits/vegetables in order to improve wages of rural females on competitive basis. They should also be educated about the importance (in terms of disease treatment and long-run health costs) of using safety precautions while working in vegetables fields. The government or extension department may provide protective masks at highly subsidized prices to the female workers working either in vegetable picking activities in other crops.

\section{References}

Anonymous. (2008). Improving Women's Skills, Published in Dawn, December 22, 2008. http://www.dawn.com/news/967571/improving-women-s-skills.

FAFEN. (2010). Free and Fair Election Network, http://www.fafen.org/

FAO. (2003). The Uplift and Empowerment of Rural Women in Pakistan. FAO, Rome, http://www.fao.org/sd/2003/kno506a-em.htm. 
FAO. (2011). The State of Food and Agriculture, Women in Agriculture, Closing the Gender Gap for Development, FAO, http://www.fao.org/docrep/013/i2050e/ i2050e.pdf

FAO. (2011). Women Agriculture and Rural Development, a Synthesis Report of the Near East Region, FAO, Rome, http://www.fao.org/docrep/meeting/030/ mj288e.pdf

Farooq, M. \& D.J. Sulaiman. (2007). Gender Earnings Inequality and Discrimination in Pakistani Labour Market, The Dialogue, vol. IV: 3, pp.373-385.

Greene, W. H. (2000). Econometric Analysis, International 4th Edition, New York, USA.

Josupeit, H. (2004). Women in the Fisheries Sector in Argentina, Uruguay, and Southern Brazil. FAO Fisheries Circular No. 992, Food and Agriculture Organization, Rome.

Mamoona, W.M. (2004). Proceedings of the Regional Workshop on Forests for Poverty Reduction: Can Community Forestry makes Money? FAO Corporate Document Repository, 2004.

Memon, N.A. (2013). Vegetable Exports from Pakistan, Exclusive on Vegetables. http://www.foodjournal.pk/Jan-Feb-2013/PDF-Jan-Feb-2013/Exclusive-articleDr-Noor.pdf

Taj, S., K.M. Aujla, M. Sharif \& Z. Yasmin. (2009). Gender Dimensions of Labour Participation in Vegetable Farming System in District Attock of Punjab, Pakistan, Journal of Agricultural Research, vol. 47: 1, pp.91-100.

UNDP. (2004). Gender Mainstreaming Training Resources, Database of Gender Training Resources, EAAP Publication No. 79, http://www.undp.org/content/dam/undp/ library/Environment\%20and\%20Energy/Sustainable\%20Energy/Gender_Mainstr eaming_Training_Manual_2007.pdf

World Bank. (2001). Attacking Poverty, World Development Report, 2000-2001, http://siteresources.worldbank.org/INTPOVERTY/Resources/WDR/English-FullText-Report/toc.pdf 
Rashed Saeed is Scientific Officer in Social Sciences Research Institute (PARC) at AARI, Jhang Road, Faisalabad (Punjab).

Dr. Arshed Bashir is Director of Social Sciences Research Institute (PARC) at AARI, Jhang Road, Faisalabad (Punjab).

Dr. Muhammad Qasim is Senior Scientific Officer in the Social Sciences Research Institute (PARC) at AARI, Jhang Road, Faisalabad (Punjab).

Ms. Sonila Hassan is working as Scientific Officer in the Social Sciences Research Institute (PARC) at AARI, Jhang Road, Faisalabad (Punjab). 